\title{
Effects of heat treatment of cows' milk and whey on the nutritional quality and antigenic properties
}

\author{
P J KILSHAW, L M J HEPPELL, AND J E FORD \\ Nutrition Department, National Institute for Research in Dairying, Shinfield, Reading, Berkshire
}

SUMMARY Recent experiments in guinea-pigs suggest that heat treatment applied during the manufacture of baby milk formulae reduces the immunological sensitising capacity of the cows' milk proteins. This immunological benefit must be weighed against possible damage that heat treatment may cause to the nutritional quality of the products. Severe heat treatment of skimmed milk $\left(121^{\circ} \mathrm{C}\right.$ for $20 \mathrm{~min}$ ) destroyed all the vitamin $\mathrm{B} 12$, about $60 \%$ of the thiamin and vitamin B6, $70 \%$ of the ascorbic acid, and about $30 \%$ of the folate. Available lysine was reduced by $21 \%$ and lactulose was formed $(166 \mathrm{mg} / 100 \mathrm{ml})$. Despite extensive denaturation of the whey proteins the milk retained its capacity to sensitise guinea-pigs for systemic anaphylaxis when administered orally. Animals drinking heated milk also produced circulating antibodies to $\beta$-lactoglobulin and casein, although titres were lower than for unheated milk. Unlike skimmed milk, heat-treated diafiltered whey failed to sensitise guinea-pigs orally. It caused the production of trace levels of antibodies in some of the animals, but these were specific for residual casein. We suggest that it may be possible to produce a non-sensitising baby milk without casein based on heat-denatured whey. The nutritional quality could be preserved by removing low molecular weight nutrients before heat treatment and adding back appropriate quantities later.

Heat treatment is an indispensable element of liquid milk processing technology and its principal role is to ensure the bacteriological quality. In baby milk formulae it may have another beneficial effect in that, by denaturing the milk proteins, it may reduce the capacity to evoke allergic reactions in susceptible infants. However, heating can adversely affect nutritional quality and the baby milk manufacturer has a duty to ensure that any such deterioration is reduced to a minimum, since the infant relies wholly or largely on this single food.

The work of McLaughlan et al. ${ }^{1}$ shows that severe heat treatment of milk reduces its capacity to sensitise guinea-pigs when administered orally and that certain baby milks that have been heat treated during manufacture exhibit reduced sensitising activity. McLaughlan et al. argue that heat treatment may have no serious harmful effect on nutritional value apart from some destruction of heat-labile vitamins, notably vitamin $C$, and that these can easily be added. Thus they suggest that manufacturers of baby milks 'need not strive to apply as little heat as possible to their products'.

In this paper we examine the effects of graded heat treatments of milk and whey on nutritional quality, protein denaturation, and the capacity of the products to evoke antibody production and anaphylactic sensitisation when administered to guinea-pigs orally. The nutritional consequences of heat treating milk are discussed and a possible strategy for producing a non-sensitising baby milk formula is proposed.

\section{Materials and methods}

Skimmed milk. This was prepared from combined evening and morning milk from Fresian cows.

Whey. Cheese whey $(60 \mathrm{l})$ was centrifuged at $6900 \mathrm{~g}$ in a disc bowl centrifuge to remove residual casein and fat and pasteurised at $65^{\circ} \mathrm{C}$ for $30 \mathrm{~min}$. It was then subjected to diafiltration to reduce the concentration of low molecular weight solutes (MW < 5000) 30-fold; this prevented serious precipitation of protein during subsequent heat treatment. The protein concentration was finally adjusted to its original value.

Heat treatment. Bottles of skimmed milk and diafiltered whey were heated in flowing steam at $100^{\circ} \mathrm{C}$ 
for $30 \mathrm{~min}$, or autoclaved at $115^{\circ} \mathrm{C}$ for $30 \mathrm{~min}$, or at $121^{\circ} \mathrm{C}$ for $20 \mathrm{~min}$. After cooling, the bottles were stored at $4^{\circ} \mathrm{C}$ until required for feeding.

Animals. Male Dunkin Hartley guinea-pigs (Greystone Guinea Pigs, Ringwood) were used for feeding experiments when they were 4 or 5 weeks old. Animals of the same strain served as recipients in the passive cutaneous anaphylaxis (PCA) test. The guinea-pigs were maintained on batches of FD1 diet (Labsure, Poole) that had been shown to be milk free by immunological testing.

Feeding experiments. Groups of 5 guinea-pigs were given heated or unheated skimmed milk or whey to drink for 2 weeks (each animal consumed about $100 \mathrm{ml}$ a day). The milk was then replaced with water and 9-11 days later blood samples were taken by cardiac puncture. The next day the animals were tested for systemic anaphylaxis by injecting intravenously $0.5 \mathrm{ml}$ of lightly centrifuged milk or whey.

Antibody measurements. Serum antibodies (IgG and IgG1) to individual milk proteins were determined by an enzyme-linked immunosorbent assay (ELISA). ${ }^{2}$ Alpha-casein was obtained from Sigma Chemical $\mathrm{Co}$ and the other milk proteins were gifts from colleagues. Reaginic antibodies, thought to be IgG1, were determined by PCA. Guinea-pigs were injected intradermally with $0.1 \mathrm{ml}$ of test serum followed $4 \frac{1}{2}$ hours later by an intravenous injection of $2.5 \mathrm{mg}$ milk protein and $5 \mathrm{mg}$ Evans's blue in $1.0 \mathrm{ml}$ saline. Skin reactions were measured $30 \mathrm{~min}$ later.

Determination of vitamins. Ascorbic acid was measured by the method of Deutsch and Weeks, ${ }^{3}$ and B-complex vitamins by standard assay procedures or modifications described by Buss et al. ${ }^{4}$

Biologically available lysine. Available lysine was measured by treating the sample with o-methylisourea (MIU-reactive lysine) and by a second method using sodium borohydride. These techniques are critically evaluated by Hurrell and Carpenter. ${ }^{5}$

Lactulose. This was assayed by an enzymic procedure. ${ }^{6}$

Determination of milk protein denaturation. Denaturation of $\beta$-lactoglobulin, $\alpha$-lactalbumin, $\alpha_{\mathrm{s} 1}$-casein, and $\kappa$-casein in heated skimmed milk and whey was determined by immunoassay of residual native protein. Dilutions of test samples were mixed with limiting quantities of specific antisera and the antibodies remaining unbound were measured by ELISA.
Serial 4-fold dilutions of heated and unheated skimmed milk or whey were mixed with equal volumes of rabbit antisera (anti- $\alpha$-lactalbumin, $1: 1000$; anti- $\beta$-lactoglobulin, $1: 20000$; anti- $\alpha_{51}$ casein, $1: 8000$; anti- $\alpha$-casein, $1: 32000$ ) and maintained at $4^{\circ} \mathrm{C}$ overnight. Microtitre plates (Dynatech M29) were coated by treatment with purified milk proteins $(100 \mathrm{ng}$ or $1 \mu \mathrm{g} / \mathrm{ml})$ and then washed and treated overnight at $4^{\circ} \mathrm{C}$, first with $200 \mu \mathrm{l}$ of milk-antibody mixture and then with $200 \mu$ of alkaline phosphatase goat anti-rabbit IgG conjugate (Miles Laboratories) diluted $1: 6000$. After a final wash, $200 \mu \mathrm{l}$ of disodium nitrophenyl phosphate solution $(1 \mathrm{mg} / \mathrm{ml})$ was added to all wells and the optical density (OD) at $405 \mathrm{~nm}$ measured after $30 \mathrm{~min}$ at room temperature.

For each milk protein, ODs (duplicate assays) were plotted against $\log _{10}$ dilutions of milk or whey. Heat denaturation was reflected in progressive displacement of the assay curves and some change in their shape (Figure). An OD of $0 \cdot 8$, in the middle range of the curves, was chosen for assessing the degree of displacement. The percentage of undenatured protein remaining after heat treatment was obtained from the formula: (dilution of heated sample giving OD $0 \cdot 80 /$ dilution of unheated sample giving OD $0 \cdot 80) \times 100$.

\section{Results}

Nutrient composition of unheated and heated skimmed milk. The effects of heat treatment on nutrient composition are shown in Table 1. Autoclaving at $121^{\circ} \mathrm{C}$ caused perceptible browning of the milk, $21 \%$ loss of available lysine, and a concomitant increase in lactulose to $166 \mathrm{mg} / 100 \mathrm{ml}$ (compared with a value of zero in raw milk). The content of ascorbic acid fell sharply by $72 \%$. Levels of thiamin and vitamin B6 fell progressively with increasing severity of heating to much the same extent; autoclaving at $121^{\circ} \mathrm{C}$ caused a loss of about $60 \%$. Loss of vitamin B12 was $86 \%$ after steaming for $30 \mathrm{~min}$, and was nearly complete after autoclaving. The loss of folate was greatest $(44 \%)$ after steaming for $30 \mathrm{~min}$. The more severe heat treatments caused appreciably smaller losses.

There was little or no loss of riboflavin, nicotinic acid, or pantothenic acid.

Heat denaturation of the major proteins in milk and whey. The Figure shows displacement of the assay curves for $\alpha$-lactalbumin in heated milk. Results obtained from these curves and from similar assays for the other proteins are shown in Table 2. Betalactoglobulin and $\alpha$-lactalbumin were extensively denatured by the mildest heat treatment. In contrast, 


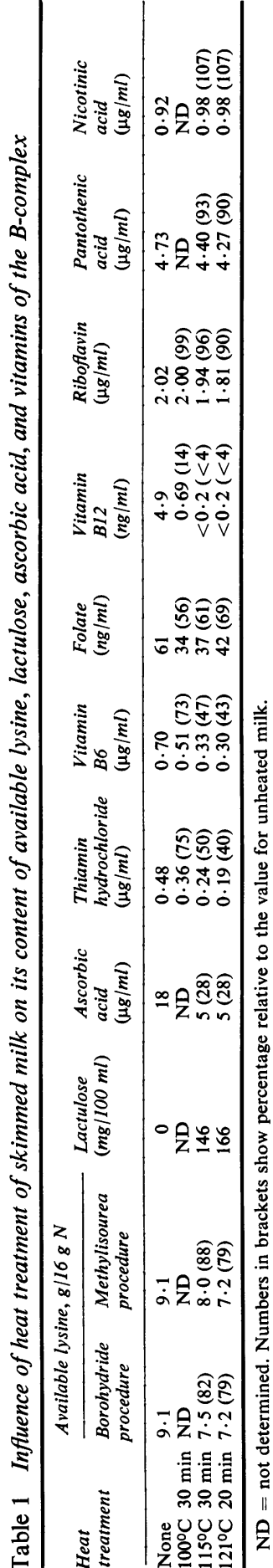

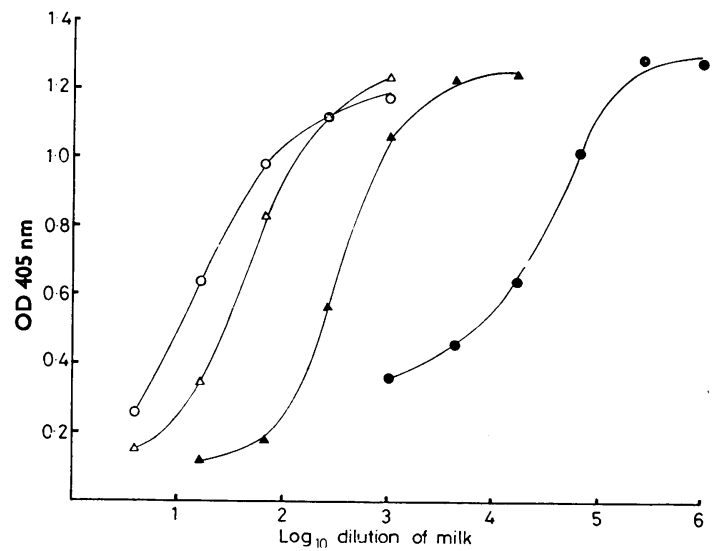

Figure Inhibition enzyme-linked immunosorbent assay for undenatured $\alpha$-lactalbumin in unheated and heated skimmed milk. The scale on the ordinate reflects the level of specific antibodies remaining unbound after mixing dilutions of milk with a standard quantity of antiserum. Unheated $(\bullet) ; 100^{\circ} \mathrm{C}, 30 \min (\Delta) ; 115^{\circ} \mathrm{C}, 30 \min (\Delta)$; $121^{\circ} \mathrm{C}, 20 \min (\mathrm{O})$.

$\kappa$-casein was unaffected by all the treatments, and $\alpha_{s_{1}}$-casein showed a progressive increase in antibodybinding capacity with more severe heating. Immuno- $\delta \overrightarrow{0}$ assay of proteins in whey showed that levels of casein were 250 to 1000 -fold lower than in milk and 6 were little affected by heating. Denaturation of $\beta$-lactoglobulin was more severe in whey than in skimmed milk and a slight trend in the reverse direction was observed for $\alpha$-lactalbumin heated to $100^{\circ} \mathrm{C}$.

Anaphylactic sensitisation and antibody production in guinea-pigs given heated or unheated skimmed milk to drink for 2 weeks. Heating had very little effect on the capacity of milk to sensitise the animals for fatal systemic anaphylaxis (Table 3). Furthermore, total IgG antibodies to $\beta$-lactoglobulin and the caseins, measured by ELISA, were only slightly lower in animals given severely heated milk than in those receiving raw milk. However, $\beta$-lactoglobulin antibodies of the IgG1 subclass, appeared to be preferentially depressed in the groups receiving heated milks. The PCA test failed to show antibodies to whey proteins in animals given heated milk and was negative for antibodies to casein in the majority of animals given the two most severely heated milks. It was therefore a less sensitive indicator of anaphylactic sensitisation than direct intravenous challenge.

Anaphylactic sensitisation and antibody production in guinea-pigs given pasteurised or more severely heated whey to drink for 2 weeks. Guinea-pigs given 
Table 2 Residual undenatured protein in heated skimmed milk and whey (\%)

\begin{tabular}{lcccc}
\hline Heat treatment & $\beta$-lactoglobulin & $\alpha$-lactalbumin & $\alpha_{\mathbf{S}_{1}}$-casein & $\kappa$-casein \\
\hline Milk & & & & 100 \\
$100^{\circ} \mathrm{C} 30 \mathrm{~min}$ & 2.3 & 1.4 & 130 & 100 \\
$115^{\circ} \mathrm{C} 30 \mathrm{~min}$ & 1.2 & 0.18 & 320 & 100 \\
$121^{\circ} \mathrm{C} 20 \mathrm{~min}$ & 0.93 & 0.086 & 540 & $0 \cdot 11$ \\
Whey & 100 & 100 & 0.40 & 0.093 \\
Pasteurisation only & 0.16 & 2.9 & 0.20 & 0.085 \\
$100^{\circ} \mathrm{C} 30 \mathrm{~min}$ & 0.075 & 0.18 & 0.27 & \\
$115^{\circ} \mathrm{C} 30 \mathrm{~min}$ & &
\end{tabular}

Table 3 Anaphylaxis and antibody production in guinea-pigs fed unheated or heated skimmed milk

\begin{tabular}{|c|c|c|c|c|c|c|c|c|c|}
\hline \multirow{2}{*}{$\begin{array}{l}\text { Heat } \\
\text { treatment }\end{array}$} & \multirow{2}{*}{$\begin{array}{l}\text { Fatal anaphylaxis } \\
\text { on IV injection of } \\
\text { milk fed* }\end{array}$} & \multicolumn{4}{|c|}{ Sera giving positive $P C A$ reactions } & \multicolumn{4}{|c|}{ Serum antibodies (mean IgG titres $\pm S D$ ) } \\
\hline & & $\begin{array}{l}\text { To } \beta \text {-lacto- } \\
\text { globulin }\end{array}$ & $\begin{array}{l}\text { To } \alpha \text {-lact- } \\
\text { albumin }\end{array}$ & To $\alpha$-casein & To k-casein & $\begin{array}{l}\text { To } \beta \text {-lacto- } \\
\text { globulin }\end{array}$ & $\begin{array}{l}\text { To } \alpha \text {-lact- } \\
\text { albumin }\end{array}$ & To $\alpha$-casein & To k-casein \\
\hline None & $5 / 5$ & $5 / 5$ & $3 / 5$ & $5 / 5$ & $0 / 5$ & \multirow{4}{*}{$\begin{array}{c}5 \cdot 2 \pm 1 \cdot 6 \\
(5 \cdot 8 \pm 1 \cdot 6) \dagger \\
5 \cdot 5 \pm 0.4 \\
(3 \cdot 4 \pm 0 \cdot 5) \dagger \\
4 \cdot 2 \pm 0 \cdot 8 \\
(0 \cdot 7 \pm 0 \cdot 6) \dagger \\
4 \cdot 2 \pm 0 \cdot 7 \\
(2 \cdot 0 \pm 1 \cdot 4) \dagger\end{array}$} & Negative & $8 \cdot 1 \pm 1 \cdot 7$ & $4 \cdot 1 \pm 1 \cdot 8$ \\
\hline $100^{\circ} \mathrm{C} 30 \mathrm{~min}$ & $5 / 5$ & $0 / 5$ & $0 / 5$ & $4 / 5$ & $0 / 5$ & & Negative & $7 \cdot 8 \pm 1 \cdot 1$ & $5 \cdot 7 \pm 2 \cdot 0$ \\
\hline $115^{\circ} \mathrm{C} 30 \mathrm{~min}$ & $4 / 4$ & $0 / 5$ & $0 / 5$ & $1 / 5$ & $0 / 5$ & & Negative & $6 \cdot 7 \pm 0 \cdot 7$ & $4 \cdot 8 \pm 1 \cdot 5$ \\
\hline $121^{\circ} \mathrm{C} 20 \mathrm{~min}$ & $4 / 5$ & $0 / 5$ & $0 / 5$ & $1 / 5$ & $0 / 5$ & & Negative & $5 \cdot 6 \pm 2 \cdot 3$ & $3 \cdot 9 \pm 1 \cdot 7$ \\
\hline
\end{tabular}

* Animals on milk-free diets were unaffected by intravenous (IV) injection of heated or unheated milk, tresults in brackets show IgG1 antibodies.

Serum antibody titres (doubling dilutions from $1: 20$ ) were determined by ELISA; sera from animals that had not received milk gave negative results when tested against the four milk proteins.

Table 4 Anaphylaxis and antibody production in guinea-pigs fed pasteurised or more severely heated whey

\begin{tabular}{|c|c|c|c|c|c|c|c|c|}
\hline \multirow{2}{*}{$\begin{array}{l}\text { Heat treatment } \\
\text { after } \\
\text { pasteurisation }\end{array}$} & \multicolumn{2}{|c|}{ Fatal anaphylaxis on injection } & \multicolumn{3}{|c|}{ Sera giving positive $P C A$ reactions } & \multicolumn{3}{|c|}{ Serum antibodies (mean IgG titres $\pm S D$ ) } \\
\hline & Of whey fed & $\begin{array}{l}\text { Of unheated } \\
\text { skimmed milk }\end{array}$ & $\begin{array}{l}\text { To } \beta \text {-lacto- } \\
\text { globulin }\end{array}$ & $\begin{array}{l}\text { To } \alpha \text {-lact- } \\
\text { albumin }\end{array}$ & To $\alpha$-casein & $\begin{array}{l}\text { To } \beta \text {-lacto- } \\
\text { globulin }\end{array}$ & To $\alpha$-lactalbumin & To $\alpha$-casein \\
\hline None & $3 / 3$ & NT & $5 / 5$ & $5 / 5$ & $0 / 5$ & $7 \cdot 6 \pm 0 \cdot 9$ & $\begin{array}{l}0.2 \pm 0.4 \\
\text { (1/5 positive) }\end{array}$ & $1 \cdot 8 \pm 1 \cdot 3$ \\
\hline $100^{\circ} \mathrm{C} 30 \mathrm{~min}$ & $0 / 5^{*}$ & NT & $0 / 5$ & $0 / 5$ & $0 / 5$ & Negative & Negative & $\begin{array}{l}1 \cdot 1 \pm 1 \cdot 1 \\
\text { (4/5 positive) }\end{array}$ \\
\hline $115^{\circ} \mathrm{C} 30 \mathrm{~min}$ & NT & $0 / 5^{*}$ & $0 / 5$ & $0 / 5$ & $0 / 5$ & Negative & Negative & $\begin{array}{l}0 \cdot 3 \pm 0 \cdot 7 \\
(1 / 5 \text { positive })\end{array}$ \\
\hline
\end{tabular}

NT $=$ not tested, PCA = passive cutaneous anaphylaxis.

* No sub-lethal anaphylactic reactions.

Animals that' had not received whey in their diets were unaffected by intravenous injection of pasteurised or severely heated whey. Serum antibody titres (doubling dilutions from $1: 20$ ) were determined by ELISA; if only a proportion of animals in a group gave positive results this is shown in brackets.

pasteurised whey were sensitised for fatal anaphylaxis and gave positive results in the PCA test against $\beta$-lactoglobulin and $\alpha$-lactalbumin (Table 4). The ELISA showed high titres of IgG antibodies to $\beta$-lactoglobulin and trace levels to casein. Antibodies to $\alpha$-lactalbumin were detected in only one animal, but we believe that for technical reasons this assay was slightly less sensitive than the others.

Animals given pasteurised whey that had received additional heat treatment did not show anaphylaxis after intravenous injection of either heated whey or unheated milk and gave negative results in the PCA test. Trace levels of IgG antibodies to $\alpha$-casein were detected by ELISA in some of the guinea-pigs.

\section{Discussion}

There are two main questions. Firstly, how does heating affect the nutritional quality of cows' milk and how necessary is it that manufacturers of baby milks should minimise the heat treatment applied to their products? Secondly, is it possible to heat denature milk proteins so as to make them nonimmunogenic and would it be worthwhile in the manufacture of infant milk formulae?

Nutritional considerations. Severe heat treatment of milk caused substantial loss of several vitamins: thiamin, vitamin B6, ascorbate, folate, and vitamin B12. The dehydro form of ascorbate, which is produced on heating milk, is involved in a variety of oxidative browning reactions and in the destruction of folate and vitamin B12.78 However, destruction of these last three vitamins can be prevented by removal of dissolved oxygen from 
the milk, a procedure used in the preparation of some ultra heat-treated milk.

Ascorbate can easily be added to heat-treated milk and this is necessary anyway because the level in human milk is more than twice that in cows' milk, but replacement or supplementation of folate is less straightforward. Folic acid is generally used for this purpose but folate in milk is in the form of $5 N$-methyl-tetrahydrofolate and folic acid may be less biologically available, if not positively harmful. ${ }^{9}$

Considerable loss of vitamin B6 occurred during heat treatment. The mechanism is not well understood but probably involves the binding of pyridoxal to protein to form $\epsilon$-pyridoxyllysine, a product known to exhibit anti-vitamin B6 activity in rats. ${ }^{10}$ So, although vitamin B6 is abundant in cows' milk it would be unsafe to assume that its partial loss on heating is of no nutritional consequence.

Heat treatment at $121^{\circ} \mathrm{C}$ caused marked browning and reduced the available lysine content by $21 \%$. Human and bovine milk protein contain similar quantities of lysine so this reduction may appreciably impair the protein nutritional quality of the milk. Loss of lysine occurs through its interaction with reducing sugars in the Maillard reaction to form biologically unavailable deoxyketosyl derivatives. It has been suggested that early products of the Maillard reaction may exacerbate milk allergic reactions in susceptible subjects. ${ }^{11}$ Advanced Maillard reactions, which cause browning, reduce the availability of other amino-acids and may have additional undesirable consequences for nutrition (see reference 12 for a review).

Another product formed during the heat treatment of milk was lactulose, a disaccharide derived from lactose. It is poorly absorbed from the gut and ferments in the colon to form acetic and lactic acids. It is known to have a laxative effect and there is evidence to suggest that lactulose in sterilised liquid baby milks may prolong diarrhoea in babies recovering from gastroenteritis. ${ }^{13}$

Some degree of heat treatment during the manufacture of formula feeds is clearly necessary but from a nutritional standpoint it should be no more severe or prolonged than is required to ensure bacteriological quality.

Immunological considerations. The value of experiments in guinea-pigs in predicting the allergenicity of foods for man is uncertain. Guineapigs were chosen because they respond readily to food protein antigens newly introduced into their diet by becoming anaphylactically sensitised and producing high levels of antibodies in the serum. Our finding that heat treatment almost completely abolished the sensitising capacity of whey provides, if not a reliable prediction for man, at least a logical starting point for clinical investigations.

It has long been known that whey proteins are easily denatured by heat but that casein is highly resistant. The three-dimensional structure of $\beta$-lactoglobulin and $\alpha$-lactalbumin becomes disorganised through cleavage of hydrophobic bonds, rearrangement of disulphide bridges, and aggregation, whereas casein has neither secondary nor tertiary structure and is not so easily modified.

Heat treatment at $100^{\circ} \mathrm{C}$ caused more severe denaturation of $\beta$-lactoglobulin in diafiltered whey than in skimmed milk and there was a slight trend in the reverse direction for $\alpha$-lactalbumin heated to $100^{\circ} \mathrm{C}$. These observations are consistent with kinetic studies showing that changes in the concentration of total solids in whey have opposite effects on the rates of thermal denaturation of the two proteins. $^{14}$ Kappa-casein was unaffected by heat whereas $\alpha_{\mathrm{s} 1}$-casein showed an increased capacity to bind specific antibodies. This apparent anomaly may reflect changes in the accessibility of antigenic determinants within casein micelles.

The results show that severe heating destroyed the anaphylactic sensitising capacity of $\beta$-lactoglobulin and $\alpha$-lactalbumin and reduced that of casein. They are therefore in general agreement with previous findings. ${ }^{15-17}$ That antibody production to casein was reduced at all seems to conflict with the observation in our serological test that heating increased the antibody binding capacity of $\alpha_{s 1}$ casein. The immune response in the guinea-pigs depends on absorption of undigested antigens from the gut and it is conceivable that casein in heated milk may have been less well absorbed than casein in raw milk.

Animals drinking heated milk produced IgG antibodies to $\beta$-lactoglobulin, detected by ELISA but not PCA. This was so even though undenatured $\beta$-lactoglobulin was present at only $1-2 \%$ of its concentration in unheated milk. Production of the IgG1 subclass seemed to be more susceptible to this reduction in antigen dose. Animals given heated whey, in which $\beta$-lactoglobulin was more severely denatured, failed to produce antibodies to $\beta$ lactoglobulin or $\alpha$-lactalbumin and were not anaphylactically sensitised, although some developed trace levels of antibodies to residual casein.

Diagnosis of cows' milk allergy in babies is often unsatisfactory and assessments of its incidence, generally $1-2 \%,{ }^{18}$ are based on recognition of overt or fulminant forms of the disease. But milk allergy may have wider significance in infantile atopic eczema. ${ }^{19}$ Exclusive breast feeding has reduced the incidence of atopic disease in some studies ${ }^{2021}$ but 
the matter is controversial ${ }^{22-24}$ and it is not clear whether the benefits of breast feeding acrue from avoidance of cows' milk antigens or from a protective propensity of mother's milk. Breast feeding is best for most babies but artificial feeds must be available and a non-sensitising preparation would be especially valuable for infants with suspected milk allergy or for those considered to be at risk. The latter category would include infants with a family history of atopic disease, babies recovering from acute infective enteritis and, possibly, preterm babies under intensive care. Our data suggest that it may be feasible to produce a non-sensitising formula based on heat-denatured whey proteins without casein.

Conclusion. Breast milk offers an optimal array of nutrients and protective factors and the artificially reared baby is already at a disadvantage in being given a poor facsimile. We feel that it would be unwise to apply severe heat treatment indiscriminately in the preparation of baby formulae for it would degrade nutritional quality in an uncontrolled manner and, because of the stability of casein, would be unlikely to abolish antigenicity. It may be possible to prepare a non-sensitising formula based on heat denatured whey proteins. To achieve optimal immunological benefits and nutritional quality low molecular weight solutes should be depleted before heat treatment. This would minimise Maillard damage and secure maximum denaturation of $\beta$-lactoglobulin. To restore nutritional quality it would be necessary to add back carbohydrate, vitamins, and minerals in suitable proportions.

We thank Mr G R Andrews for help in preparing the whey and for the measurements of lactulose; Mr J D Edwards-Webb for assaying ascorbate; Dr R L J Lyster for the gift of antisera and purified whey proteins; $\operatorname{Dr}$ A T Andrews for providing $\kappa$-casein; Dr D Knight for amino-acid analysis.

\section{References}

1 McLaughlan P, Anderson K J, Widdowson E M, Coombs R R A. Effect of heat treatment on the anaphylactic sensitising capacity of cows' milk, goats' milk, and various infant formulae fed to guinea pigs. Arch Dis Child 1981 ; 56: 165-71.

2 Heppell L M J, Kilshaw P J. Immune response of guinea pigs to dietary protein. I. Induction of tolerance by feeding with ovalbumin. Int Arch Allergy Appl Immunol 1982; 68: 54-9.

3 Deutsch M J, Weeks C E. Microfluorometric assay for vitamin C. J Assoc Off Agric Chem 1965; 48: 1248-56.

4 Buss D H, Ford J E, Scott K J. The B-vitamin content of baboon (Papio cynocephalus) milk. Br J Nutr 1977; 38: 507-11.

5 Hurrell R F, Carpenter K J. Mechanisms of heat damage in proteins. IV. The reactive lysine content of heat- damaged material as measured in different ways. $\mathrm{Br} J$ Nutr 1974 ; 32: 589-603.

6 Geier H, Klostermeyer H. Enzymatische Bestimmung von Lactulose. Z Lebensm Unters Forsch 1980 ; 171 : 443-5.

7 Ford J E. Factors influencing the destruction by heat of vitamin B12 in milk. $J$ Dairy Res 1957; 24: 360-5.

8 Ford J E. The influence of the dissolved oxygen in milk on the stability of some vitamins towards heating and during subsequent exposure to sunlight. $J$ Dairy Res 1967; 34: 239-47.

9 Barford P A, Pheasant A E. Letter: Trial of folate treatment to prevent recurrence of neural tube defects. $\mathrm{Br}$ Med J 1981; 282: 1793.

10 Gregory J F, Kirk J R. Vitamin B6 activity for rats of €-pyridoxyllysine bound to dietary protein. J Nutr 1978; 108: 1192-9.

11 Bleumink E. Food allergy and the gastrointestinal tract. In: Asquith $\mathrm{P}$, ed. Immunology of the gastrointestinal tract. Edinburgh: Churchill Livingstone, 1979: 195-213.

12 Adrian J. Nutritional and physiological consequences of the Maillard reaction. World Rev Nutr Diet 1974; 19: 71-122.

13 Hendrickse R G, Wooldridge M A W, Russell A. Lactulose in baby milks causing diarrhoea simulating lactose intolerance. Br MedJ 1977; i: 1194-5.

14 Hillier R M, Lyster R L J, Cheeseman G C. Thermal denaturation of $\alpha$-lactalbumin and $\beta$-lactoglobulin in cheese whey: effect of total solids concentration and $\mathrm{pH}$. J Dairy Res 1979; 46: 103-11.

15 Ratner B, Dworetzky M, Oguri S, Aschheim L. Studies on the allergenicity of cows' milk. II. Effect of heat treatment on the allergenicity of milk and protein fractions from milk as tested in guinea pigs by parenteral sensitization and challenge. Pediatrics 1958; 22: 648-52.

16 Ratner B, Dworetzky M, Oguri S, Aschheim L. Studies on the allergenicity of cows' milk. III. Effects of heat treatment on the allergenicity of milk and protein fractions from milk as tested in guinea pigs by sensitization and challenge by the oral route. Pediatrics $1958 ; 22$ : $653-8$.

17 Anderson K J, McLaughlan P, Devey M E, Coombs R R A. Anaphylactic sensitivity of guinea pigs drinking different preparations of cows' milk and infant formulae. Clin Exp Immunol 1979; 35: 454-61.

18 Savilahti E. Cow's milk allergy. Allergy 1981; 36: 73-88.

19 Atherton D J, Sewell M, Soothill J F, Wells R S, Chilvers C E D. A double blind controlled crossover trial of an antigen avoidance diet in atopic eczema. Lancet 1978; i: 401-3.

20 Matthew D J, Taylor B, Norman A P, Turner M W, Soothill J F. Prevention of eczema. Lancet 1977 ; i: $321-4$.

21 Saarinen U M, Kajosaari M, Backman A, Siimes M. Prolonged breast feeding as prophylaxis for atopic disease. Lancet 1979; ii: 163-6.

22 Gordon R R, Noble D A, Milford Ward A, Allen R. Immunoglobulin $\mathrm{E}$ and the eczema-asthma syndrome in early childhood. Lancet $1982 ;$ i : $72-4$.

${ }^{23}$ Kramer M S, Moroz B. Do breast feeding and delayed introduction of solid foods protect against subsequent atopic eczema? J Pediatr 1981 ; 98: 546-50.

24 Midwinter R E, Moore W J, Soothill J F, Turner M W, Colley J R T. Letter: Infant feeding and atopy. Lancet 1982 ; i: 339.

Correspondence to $\operatorname{Dr}$ P J Kilshaw, Nutrition Department, National Institute for Research in Dairying, Shinfield, Reading RG2 9AT, Berkshire.

Received 23 April 1982 